\title{
Structural Analysis and 3D Timber Spatial Structure Modeling
}

\author{
Tatiana Budko ${ }^{1}$, Lyudmila Lavrinenko² \\ 1,2 Kyiv National University of Civil Engineering and Architecture \\ 31, Povitroflotsky Ave., Kyiv, 03037, Ukraine \\ 1tatiana.budko98@gmail.com, http://orcid.org/0000-0002-3162-8197 \\ 2 ludmila.lavrinenko@gmail.com, http://orcid.org/0000-0001-5601-0943
}

DOI: $10.32347 / 2522-4182.8 .2021 .4-16$

Summary The analysis of the structural form of the multi-volume dome structure using loadbearing wooden arches is performed. The complexity of the volumes and their connecting lines, as well as the requirement to conduct a non-linear analysis of long-span wooden elements at the request of Eurocode 5 make the information model necessary. It is noted that the design using this technology is developing in the direction of taking into account all stages of the structure life cycle. Information modeling of wooden structures in the world is the most prepared for the use of BIMtechnologies. This is due to the sophisticated digital technologies for the production of modern wooden structures elements. An information model was formed for designing according to the regulations of Ukraine. The Information Model was created in the SAPFIR software package for further possibility of importing the model into the LIRACAD software package. The necessary auxiliary steps were used to build the model. The loads on the curved surface were calculated in the PC Espri. For further development of the nodes, 3Dmodeling was used with the transfer of the information model into the PC Tekla Structures as a specialized environment for the constructive section of the project.

The presented analysis of the complex dome structure using wooden arches summarizes the approaches to the development of unique forms of structures using wood. The use of information models has significantly increased the complexity of architectural design and structural model taking into account the nonlinear effects of wood. The possibility of integrating these tools for further implementation in BIM-technology is shown.

Keywordsl. BIM-technology; timber bentglued structures; arched covering; aquapark;

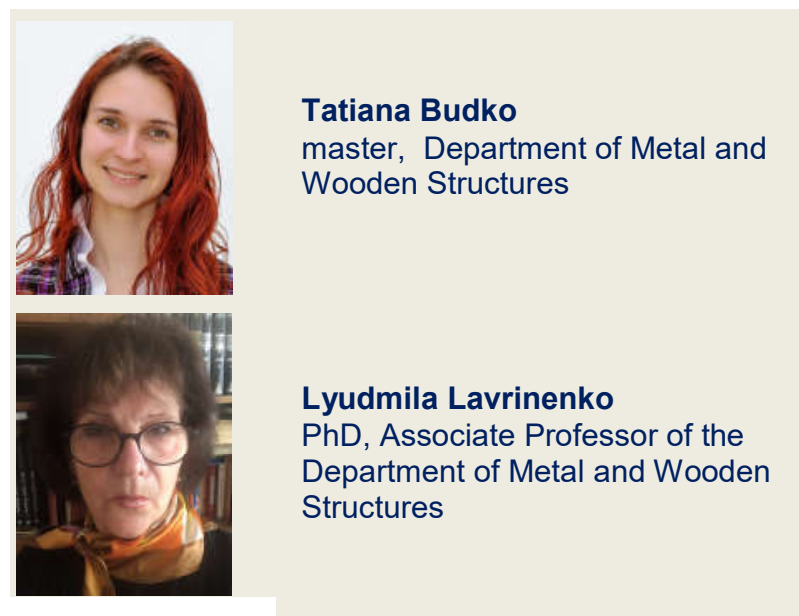

Eurocode 5.

\section{INTRODUCTION}

Modern building design technologies enable to create complex structures, and 3D information technologies assume to form sophisticated object models. The use of BIM technologies (Building Information Modeling) is one of the most promising developments in the field of architecture, technology and construction in recent years. BIM is both a new technology and a new way of working that provides a common environment for all the information that defines a building at all (or possible) stages of its life cycle, taking into account the architectural, structural and technological parameters of the building [1,2].

The methods of 3D BIM technologies have been introduced into the educational process of the Department of Metal and Wooden structures of KNUBA since 2016-2017 [3]. When 


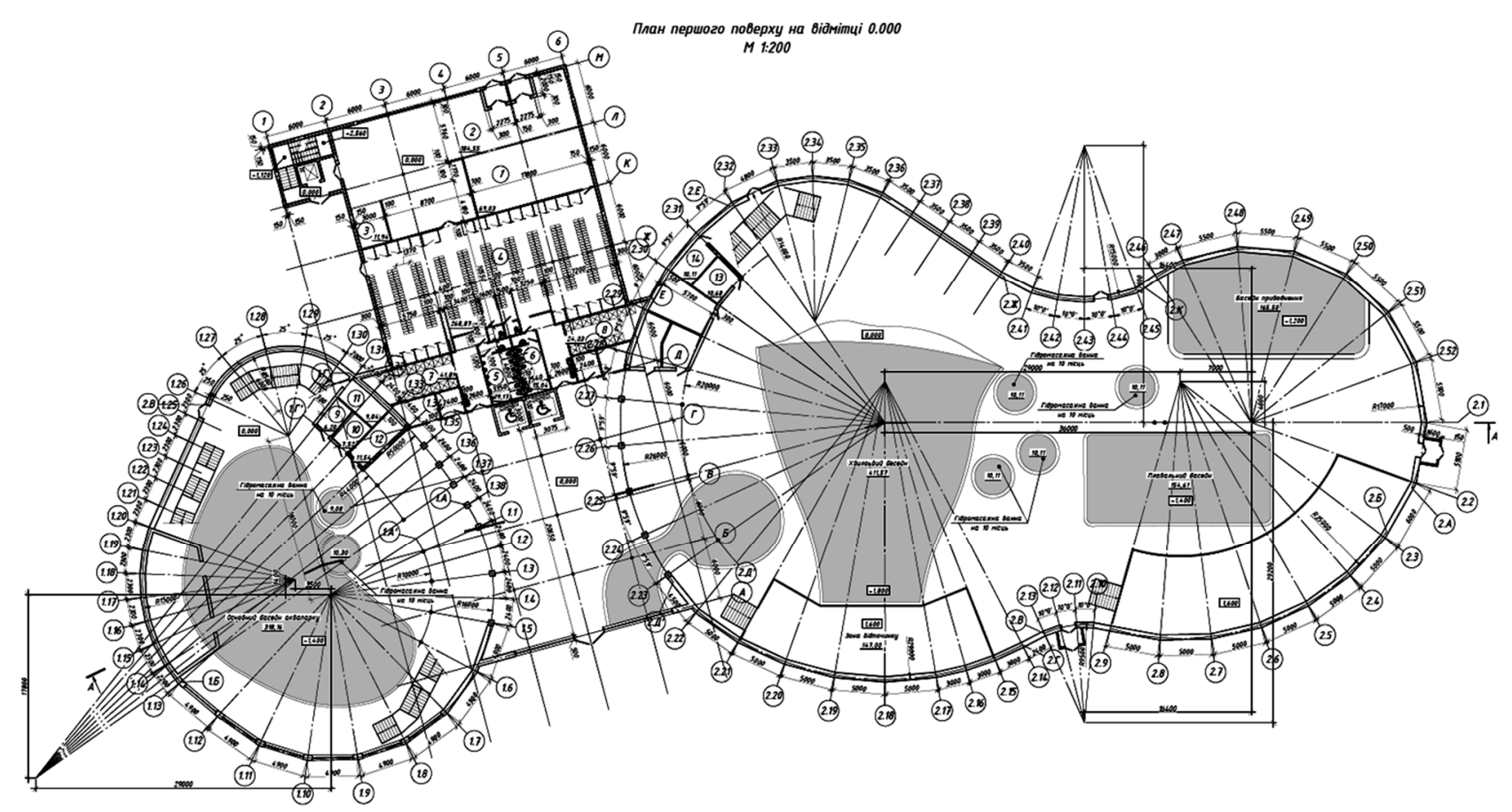

Fig. 1. Architectural proposal: plan of the first floor at 0.000

Рис. 1. Архітектурна пропозиція: план на відмітці 0,000 using them, the possibilities of using the 3D structure modeling are widely revealed $[2,4]$.

At the present stage, the wood construction practice is promising for the use of both solid (round logs, profiled beams), glued elements, and plates and beams LVL, OSB.. Their work and characteristic values of resistance differ significantly. For the popularization of unique and environmentally friendly architectural solutions, glued laminated timber provides the most cost-effective way to form a structure of complex shape $[4,5]$.

At the same time, savings of material and labor resources are provided, energy efficiency is increased both at the construction stage and during operation [6]. However, the scale of the application of glued wood materials and LVL is complicated by problems that are due to the specific properties of wood.

Features of modern complex wooden construction are considered on the example of the aquapark project (Fig. 1). For specific conditions of the water park, the limited use of steel structures is due not only to direct corrosion, but also to the fact that the use of glued beams reduces the number of auxiliary parts and nodes that require appropriate protection [7].

\section{ANALYSIS OF THE RECENT RESEARCH AND PROBLEM STATEMENT}

Based on the generalized data of the experience of domestic and foreign construction, a positive opinion is formed that the use of glued wooden structures in the construction of public and sports facilities is rational $[4,6]$.

Taking into account all stages of the life cycle of timber structures requires the use of new design technologies. The use of information modeling changes the traditional way of providing information based on text documents and two-dimensional drawings.

New integrated technologies are introduced primarily in those countries where the industry of wood processing and fabrication of building structures from wood and wood-based materials is developing. With the proliferation and growing interest in Building Information Modeling (BIM), level of detail issues are being addressed more and more successfully. And interoperability and integration of modelbased application into an overall high productive workflow has emerged to the forefront of professional attention [11, 12]. In modeling, much attention is paid to solving analysis of related engineering problems, coordination of $2 \mathrm{D}$ and $3 \mathrm{D}$ models, coordination of infor- 
mation and more. When the 3D model is linked with time (the construction schedule), the result is a 4D model that can be simulated to visualize the construction process [13]. However, it is noted that BIM tools, which are to some extent mature for steel and concrete structures, are not yet completely satisfactory for modeling wooden structures, in [9] the state of BIM tools in the modeling of wooden structures is considered and the functional requirements to the BIM models regarding the development of national standards for the coordination of information from all participants in the process of developing wooden structures are formulated.

These challenges focus on improving the standardization of the BIM model for the design and analysis of wooden structures [10]. Some procedures and relationships in BIM technologies are becoming the nationally accepted BIM standard [11].

Research in the direction of BIMtechnologies for wooden structures is interdisciplinary and offers contributions to the fields of information systems, construction informatics, and construction management. It builds on and extends the discourse on BIM deployment in the architecture, engineering, and construction industry [12].

However, information modeling of modern timber construction is already more advanced than other construction methods [13]. This is due to its high degree of prefabrication and sophisticated digital processes. For decades now, 3D models for machine production have been created in workshop planning. Digitalization and automation of prefabrication are constantly developing. It is noted that design using this technology is developing in the direction of taking into account all stages of the structure life cycle. BIM systems open up a number of possibilities for the wood-based building industry, such as increasing automation and prefabrication. Higher levels of automation will become possible once project teams have succeeded in collaboratively creating digital BIM models [13]. The range of problems in integrated BIM design expands to include the problem of renovation and environmental reuse of wooden structures after the liquidation of the building [14, 15].

Only some of the modeling tasks are considered in this paper, the possibility of using existing design tools for implementation in the BIM-technological design process is analyzed. BIM-design tools are considered as means in the design (including variant design) of a spatial building, which is a multi-volume structure with complex conjugation curves (Fig. 1).

As shown in our early work [27], when designing in accordance with Ukrainian standards, it becomes more and more common to create design documentation by using the SAPFIR PC, LIRA-CAD PC, Revit PC or Tekla PC. This makes it possible to take into account the requirements of ДБН В.2.6-198 "Steel structures" and ДБН В.2.6-98 "Concrete and reinforced concrete structures", as well as use the modern system of parametric 3D modeling SAPFIR PC. Successful experience of using SAPFIR software enables to build an informational 3D BIM model of a building. SAPFIR PC includes a modern system of parametric 3D modeling, tools for creating design schemes and transferring them to

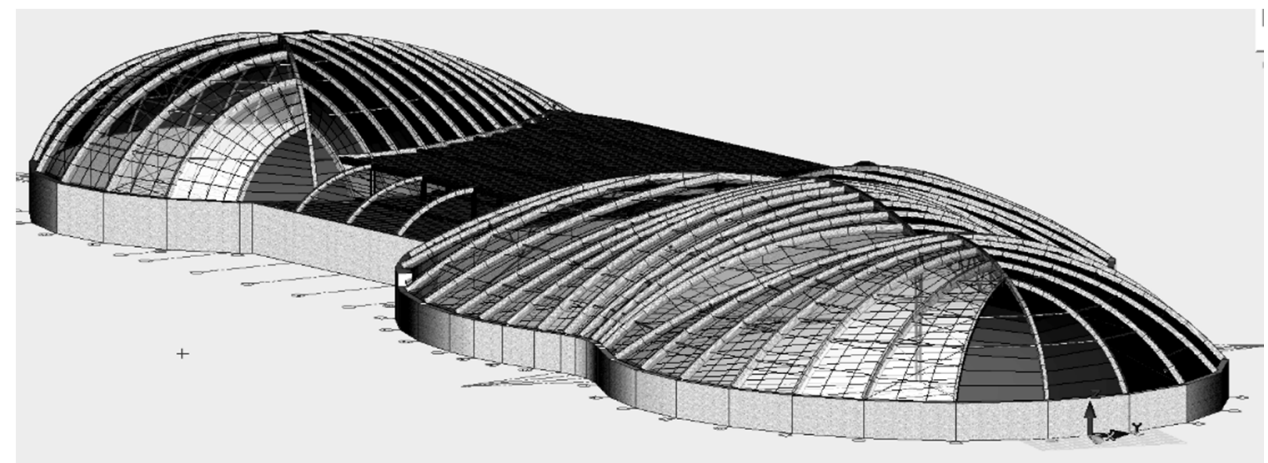

Fig. 2. The analytical model in PC SAPFIR

Рис. 2. Аналітична модель у ПК САПФИР 
calculations in LIRA-CAD software package, for calculation of building elements, obtaining drawings of structural elements. However, the designing with ДБН В.2.6-16 "Wooden structures", which agreed with Eurocode 5, still requires certain modifications to the existing software [27].

The object of study is an indoor aquapark. The basis of its planning structure is a twostorey building of complex configuration. The roof structure consists of two domes, the total length of the building is $126 \mathrm{~m}$ (Fig. 1, Fig. 2).

The building has a frame structure. Reinforced concrete walls and wooden arches provide spatial rigidity and stability of the main volume. The engineering support of the aquapark includes modern equipment with a single automated control system, air conditioning system, combined water treatment (chlorination and ozonation). All engineering chambers for ventilation, water treatment and air conditioning systems are made in the basement. Environmental cleanliness control as one of the building safety factors ensures that the chlorine content in the air does not exceed 1.0 $\mathrm{mg} / \mathrm{m} 3$ at the level of medium aggressiveness of the environment [7].

The creation of a "green" roof is considered, which helps to improve the aesthetic properties of the building and increases its thermal and sound insulation properties.

The aim of the study is to analyze and evaluate the level of integration of the spatial model of the building according to Eurocode 5 $[16,17]$ in the design environment BIM.

Research objectives are the development of a 3D information model in the PC SAPFIR and calculation of the structure in the PC LIRA-CAD; design of load-bearing structures and units, development of 3D models of units; formation of a selection of tools for BIMdesign, analysis and assessment of the integration of solutions in BIM-systems.

The analytical model used as input for further analysis (Fig 1, Fig. 2).

\section{METHODS, RESULTS AND DISCUSSION}

The ribbed, ribbed-annular and mesh types of the spatial scheme of the dome were considered [18] and an irregular ribbed-mesh scheme was chosen, the ribs of which are bent glued arches (Fig. 1, Fig. 2). Thus, while retaining the technological advantages of the ribbed scheme, our scheme received additional qualities of a spatial bar structure, which ensures high reliability of the structure in difficult extreme situations. In connection with catastrophes during the destruction of coatings, requirements were put forward for the operation of large-span structures at the stage of operation [8]. A dome with an excessive number of links (from the point of view of an optimal design) has a significantly greater survivability resource. In European standards, this is considered as "prevention of progressive collapse", that is, as an opportunity to redistribute the load between other elements in the event of failure of a certain number of elements.

The volumes of the domes are formed by arches, the outlines of which were modelled parametrically. The parametric design process

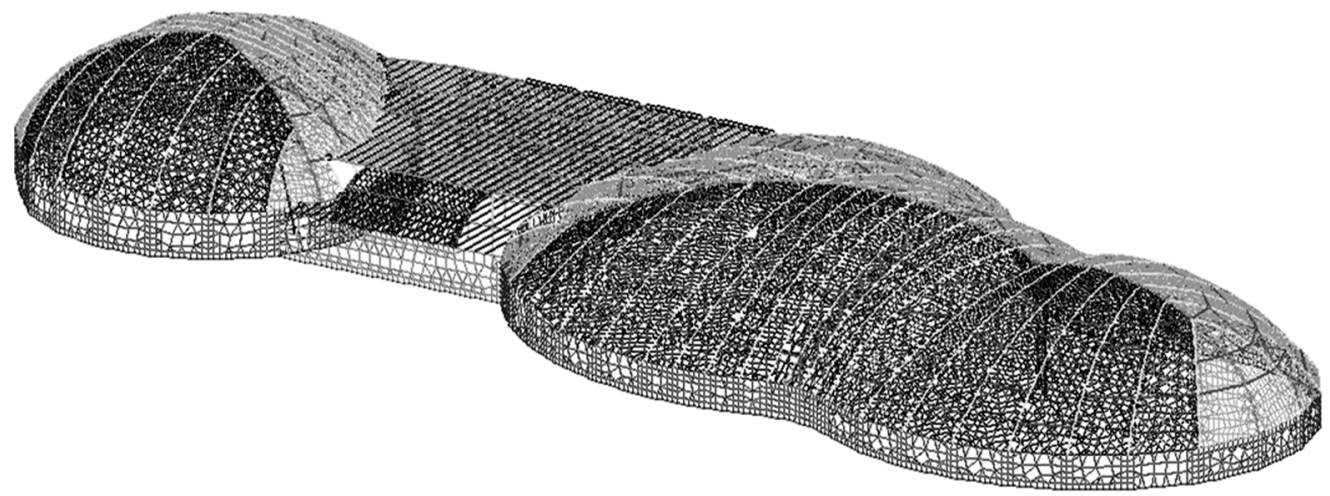

Fig. 3. The design model in PC LIRA-CAD

Рис. 3. Розрахункова модель у ПК ЛІРА -САПР 


\begin{tabular}{|c|c|}
\hline Наименование & Балка \\
\hline Слой & Конструктив \\
\hline Маркировка & Головна балка \\
\hline Цвет поверхности & нет ивета \\
\hline Материал & Древесина хвойных пород \\
\hline Интерпретация & Несущий конструктив \\
\hline \multicolumn{2}{|l|}{ 曰 Цвета } \\
\hline Цвет граней & $\square \mathrm{d} 3 \mathrm{~b} 07400$ \\
\hline Цвет линий & $\square 477 \mathrm{~cd} 1$ \\
\hline Вес пинии & Тонкая 03 \\
\hline Сечение 3D модели & Да \\
\hline Аппроксимация & 1.0 \\
\hline Контур сечения & Прямоугольный(S0) $300 \times 800$ \\
\hline \multicolumn{2}{|l|}{ 曰 Привязка сечения } \\
\hline Привязка базовой точки & Центр масс \\
\hline $\mathrm{X}, \mathrm{MM}$ & 0 \\
\hline Y.MM & 0 \\
\hline Поворот сечения. • & 0 \\
\hline Скручивание сечения & Нет \\
\hline Выравнивание аналитической мо... & Her \\
\hline Сглаживание & Нет \\
\hline Показать арматуру в 3D & Нет \\
\hline \multicolumn{2}{|l|}{$\boxminus$ Уровень оси стерхня } \\
\hline База уровня & Заданная высота \\
\hline Смещение уровня осевой. мм & -4000 \\
\hline Нижний уровень балки. мм & 2335.70 \\
\hline Длина. мм & 21612.60 \\
\hline Площадь боковая, $\mathrm{M}^{2}$ & 47.54 \\
\hline Объём. $\mathrm{M}^{3}$ & 5.187 \\
\hline Bec, $T$ & 3.112 \\
\hline \multicolumn{2}{|c|}{ 曰 Параметры аналитической модели } \\
\hline Дотягивать & Начало и конец \\
\hline Шаг разбивки стержня, М & 0 \\
\hline Точность совпадения. Мм & 0 \\
\hline Шаг аппроксимации, мм & 0 \\
\hline \multicolumn{2}{|l|}{ 曰 Параметры АЖT } \\
\hline Формировать АЖТ & Нет \\
\hline Минимальное расстояние ме... & 0 \\
\hline Форма AЖT & Авто \\
\hline Количество узпов АЖТ & 8 \\
\hline$\boxminus$ Граничные условия & \\
\hline Применять к & Вся балка \\
\hline Опирание & s:X e:0 \\
\hline & $a$ \\
\hline Наименование & Балка \\
\hline Слой & Конструктив \\
\hline Маркировка & В'язь \\
\hline Цвет поверхности & нет цвета \\
\hline Материал & Стальные конструкции \\
\hline Интерпретация & Несущий конструктив \\
\hline$\boxminus$ Lвera & \\
\hline Цвет граней & $\square \mathrm{d} 3607400$ \\
\hline Цвет линий & $\square 477 \mathrm{~cd} 1$ \\
\hline Вес линии & Тонкая 03 \\
\hline Сечение 3D модели & Да \\
\hline Алпроксимация & 1.0 \\
\hline Контур сечения & Канат $\cdot 12.0$ \\
\hline 曰 Привязка сечения & \\
\hline Привязка базовой точки & Центр масс \\
\hline $\mathrm{X} . \mathrm{Mm}$ & 0 \\
\hline Y.MM & 0 \\
\hline Поворот сечения, & 0 \\
\hline Скручивание сечения & Нет \\
\hline Выравнивание аналитической мо... & Нет \\
\hline Сглаживание & Нет \\
\hline Показать арматуру в 3D & Нет \\
\hline$\boxminus$ Уровень оси стерхняя & \\
\hline База уровня & Заданная высота \\
\hline Смещение уровня осевой. мм & 0 \\
\hline Нижний уровень балки, мм & -5.65 \\
\hline Длина. мм & 6887.11 \\
\hline Площадь боковая, $\mathrm{M}^{2}$ & 0.28 \\
\hline Объём. $\mathrm{M}^{3}$ & 0.001 \\
\hline Bec. $T$ & 0.005 \\
\hline 曰 Параметры аналитической & модели \\
\hline Дотягивать & Начало и конец \\
\hline Шаг разбивки стержня. М & 0 \\
\hline Точность совпадения, мм & 0 \\
\hline Шаг аппроксимации, мм & 0 \\
\hline 曰 Параметры AЖT & \\
\hline Формировать АЖТ & Нет \\
\hline Минимальное расстояние ме... & 0 \\
\hline Форма AЖT & Авто \\
\hline Количество узлов АЖТ & 8 \\
\hline$\Xi$ Граничные условия & \\
\hline Применять к & Вся балка \\
\hline Опирание & s:O e:O \\
\hline
\end{tabular}

$c$

\begin{tabular}{|c|c|}
\hline Наименование & Балка \\
\hline Слой & Конструктив \\
\hline Маркировка & Ребра купола \\
\hline Цвет поверхности & нет цвета \\
\hline Материал & Древесина хвойных пород \\
\hline Интерпретация & Несущий конструктив \\
\hline \multicolumn{2}{|l|}{ 曰 Цвета } \\
\hline Цвет граней & $\square \mathrm{d} 3 \mathrm{~b} 07400$ \\
\hline Цвет линий & $477 \mathrm{~cd} 1$ \\
\hline Вес пинии & Тонкая 03 \\
\hline Сечение 3D модели & Да \\
\hline Аппроксимация & 1.0 \\
\hline Контур сечения & Прямоугольный(S0) 200×700 \\
\hline \multicolumn{2}{|l|}{ 曰 Привязка сечения } \\
\hline Привязка базовой точки & Центр масс \\
\hline X.MM & 0 \\
\hline Y.MM & 0 \\
\hline Поворот сечения. ${ }^{\circ}$ & 0 \\
\hline Скручивание сечения & Нет \\
\hline Выравнивание аналитической мо... & Нет \\
\hline Сглаживание & Нет \\
\hline Показать арматуру в 3D & Нет \\
\hline \multicolumn{2}{|l|}{ 曰 Уровень оси стерхня } \\
\hline База уровня & Заданная высота \\
\hline Смещение уровня осевой. мМ & 0 \\
\hline Нижний уровень балки, мМ & -4276.27 \\
\hline Длина, мм & 25553.86 \\
\hline Площадь боковая, $\mathrm{M}^{2}$ & 45.99 \\
\hline Объём, $\mathrm{M}^{3}$ & 3.578 \\
\hline Bec, $T$ & 2.147 \\
\hline \multicolumn{2}{|c|}{ G Параметры аналитической модели } \\
\hline Дотягивать & Начало и конец \\
\hline Шаг разбивки стержня. М & 0 \\
\hline Точность совпадения, мм & 0 \\
\hline Шаг аппроксимации, мм & 0 \\
\hline \multicolumn{2}{|l|}{$\boxminus$ Параметры АЖT } \\
\hline Формировать АЖТ & Нет \\
\hline Минимальное расстояние ме... & 0 \\
\hline Форма AЖT & Авто \\
\hline Количество узлов АЖТ & 8 \\
\hline \multicolumn{2}{|l|}{ 曰 Гранинные условия } \\
\hline Применять к & Вся балка \\
\hline Опирание & s:O e:O \\
\hline
\end{tabular}

$b$

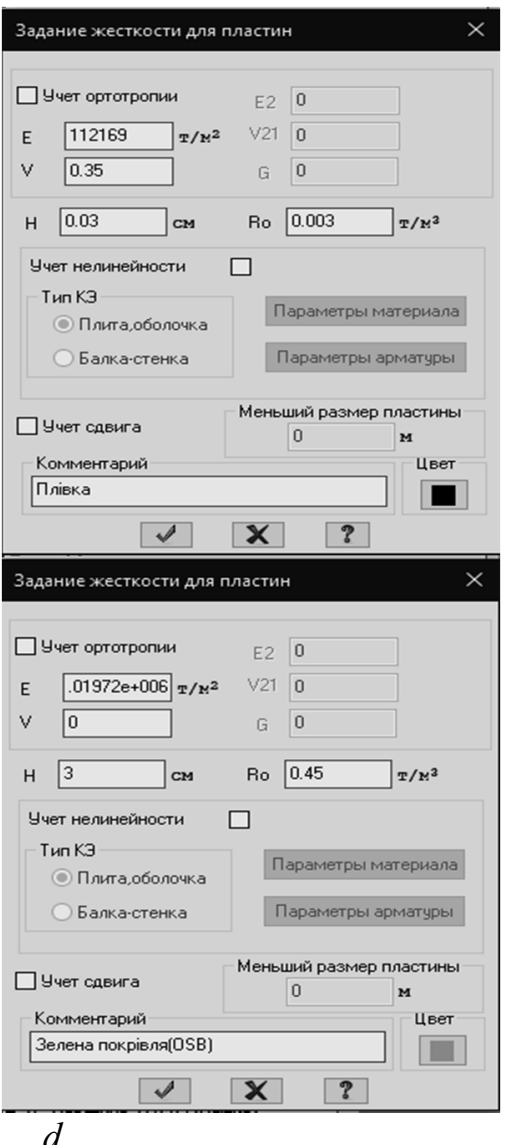

Fig. 4. Properties of elements: $a-c$-structural elements in PC SAPFIR; $d$-auxiliary plates in PC LIRA

Pис. 4 Властивості заданих елементів: $a-c$ - конструктивних елементів у ПК Сапфир; $d$ - допоміжних пластин у ПК ЛІРА 
consists of defining parameters, defining relationships between them, constructing.the expected geometry, creating variations, and testing the final product [19]. Using the concept of parameterization, the user can enter a numeric or text value for any parameter, as well as use a variable or complex expression. This admits to use the input values of the parameters defined in other programs, calculate them by formulas and change them externally [20].

The presented calculation of an irregularly shaped wooden dome summarizes the approaches to the development of unique forms of structures using wood. Along the way, a number of narrower practical issues were solved, such as uneven load on the structure, prevention of skewing, development of effective solutions for pin connections for fixing arches at different angles, etc.

3D information model development. The analytical model is designed using finite elements. In this project, this is a structural diagram, in which the elements of supporting structures are presented in the form of lines and surfaces, supplemented by ties and loads. To build the information model, the material of the supporting structure was determined (multilayer glued beams, strength class

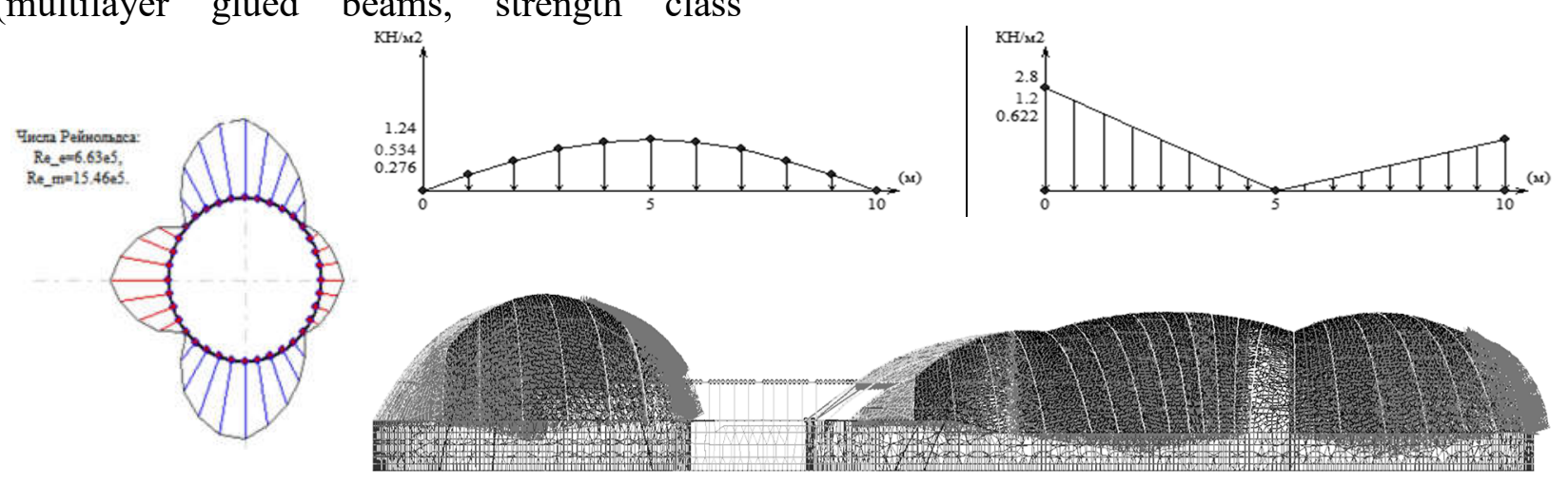

GL32h), materials and preliminary dimensions of the main elements and boundary conditions were adopted (Fig. 3, Fig. 4, $a-c$ ). A 3D surface was also built; it consists of plates, the stiffness of which is close to the real values of the coating, to transfer uneven loads to the structure (Fig. 4, $d$ ). Modeling of physical nonlinearity of structural elements was carried out using finite elements in accordance with the library of the laws of deformation of materials. As a result, the calculation made it possible to estimate the elastic and plastic deformations of the elements.

The analysis of the design model is carried out using graphical methods for presenting the results, such as diagrams of internal forces of bar elements, stress fields of the plate elements and deformable schemes. For a detailed analysis and identification of the calculated values of the forces for each element, tables of calculated load combinations were created, updated in accordance with the Eurocode.

When creating an information model, visual programming is possible [25]. An example of this is the joint use of SAPFIR-3D and SAPFIR-Generator with the subsequent possibility of importing the model into the LIRA-CAD.

Fig. 5. The wind load in PC LIRA-CAD in accordance with ДБН В.1.2-2

Рис. 5. Вітрове навантаження в ПК ЛІРА-САПР відповідно до ДБН В.1.2-2

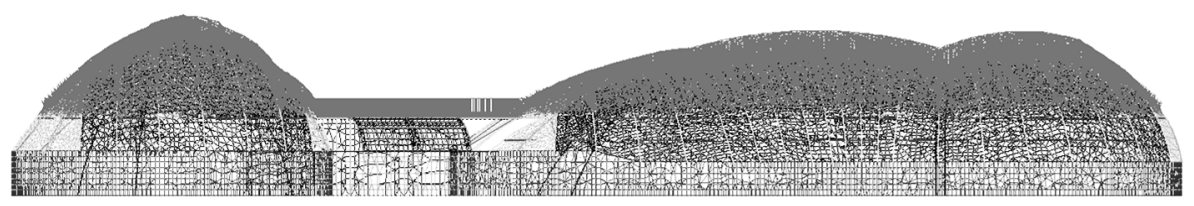

Fig. 6. The snow load in PC LIRA-CAD in accordance with ДБН В.1.2-2

Рис. 6. Снігове навантаження в ПК ЛІРА-САПР відповідно до ДБН В.1.2-2 
During the design process, great attention was paid to smooth lines along all surfaces and to minimize deflections and displacements. For this, the cross-section of each element was calculated for the corresponding loads. For example, the ribs under the "green roof" take greater loads than under the membrane roof, and the upper radius of the ribs curvature make it possible to insert OSB without interruption along the entire rib length without twisting (Fig. 4). 3D surfaces are described, these are stiffness plates close to real values for transferring non-standard fastening to a structure (Fig. $4, d)$. The tasks of ensuring sufficient and optimal cross-sectional dimensions, as well as limiting the design height according to the operating and installation conditions, have become relevant $[10,11]$. Another limitation of the supporting structure height is associated with the proposal to place technological equipment in the space between the arches.

The assessment of losses in case of deviation from the optimal values of design parameters was not carried out.

Model load in PC LIRA-CAD. The load is determined per unit area and applied to the 3D plate. Load tables for snow and wind loads were generated using the ESPRI software.

This program enables to quickly find online all parameters of the collection of loads in accordance with ДБН В.1.2-2: 2006.

At the output, we obtain tables of distributed load depending on the angle of inclination of the covering. To correctly distribute the load on the structural ribs, plate elements were created. The description of uneven loads on the roofing plate elements took place in the LIRA-CAD software package (Fig. 5, Fig. 6).

Structural elements calculation. Glued wooden arches are used as load-bearing structures, the analysis of the stress-strain state of which is carried out using a nonlinear calculation under the action of loads corresponding to real design conditions. To obtain information about the stress-strain state of the main supporting structures, a numerical simulation of the spatial structure was carried out.

Formation of an analytical model, which is a structural scheme, in which the elements of load-bearing structures are presented in the form of lines and surfaces, supplemented by constraints and loads, is performed using finite elements of the SAPFIR software and the LIRA-CAD PC.

When the parameter "Account for nonlinearity" was activated, the physical nonlinearity of deformation was set using the diagrams of deformation of wood during tension and compression along the fibers. When law 14, describing piecewise-linear dependence, is

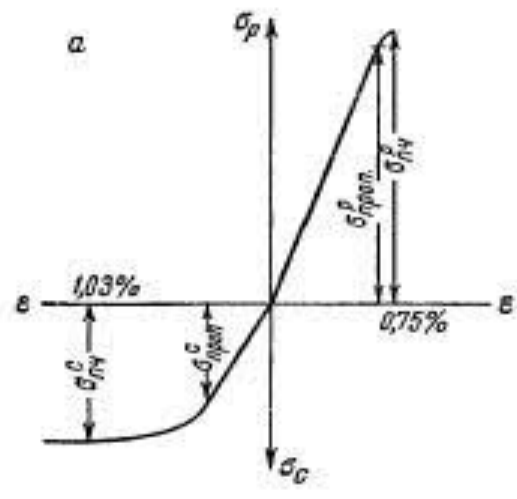

$a$

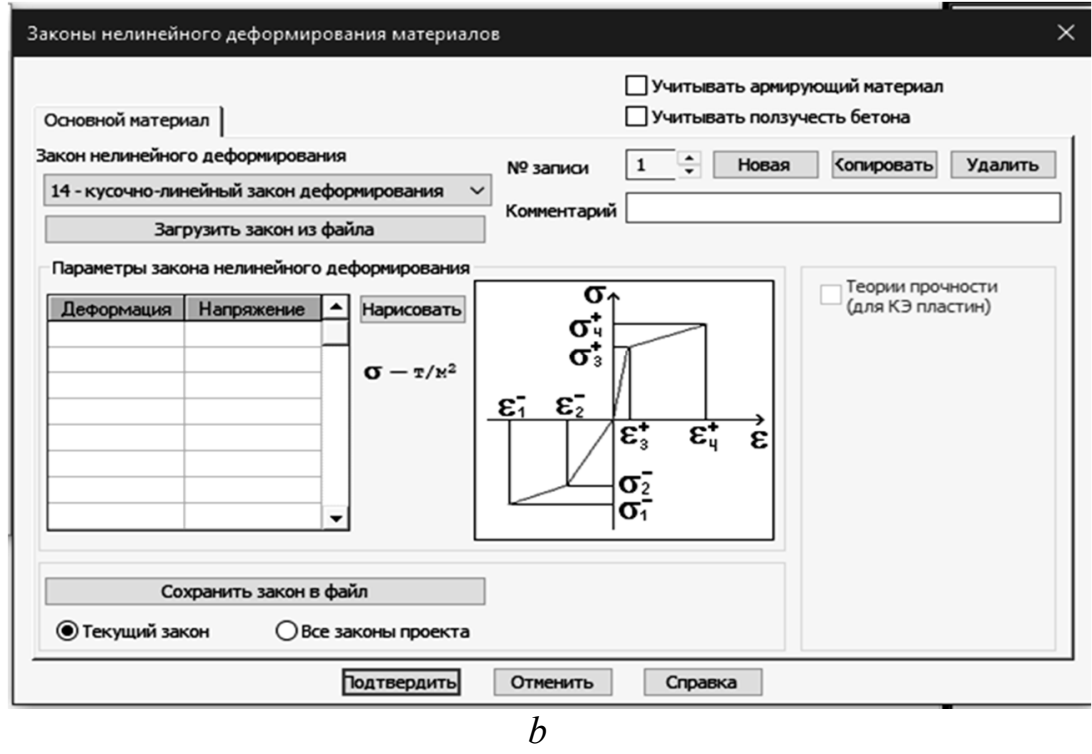

Fig. 7. Account of the wood properties $(a)$ as a physically nonlinear material in LIRA-CAD $(b)$

Рис. 7. Врахування властивостей деревини $(a)$ як фізично нелінійного матеріалу в ЛІРА -САПР $(b)$ 
chosen as a physical model, the tensile $(\sigma-\varepsilon)$ curves of the material are described as shown in Fig. 7 [26].

Geometric nonlinearity is taken into account by sequential application of loads in uniform steps, since the internal forces in the designed structure are very dependent on the sequence of their application. In such cases, a stepwise loading method is applied, and structures are modeled using elements that take into account physical nonlinearity (KЭ200), geometric nonlinearity (KЭ300), or physical and geometric nonlinearity simultaneously (КЭ400).

For a more detailed analysis of structural elements, the anisotropy of wood can be taken into account by modeling the elements using plates and three-dimensional finite elements [22]. However, taking into account the rod type of the main elements, the anisotropy of the elastic properties of wood was not taken into account. The mobility of the node can be taken into account with the optional element $\mathrm{K} \ni 55$. It is necessary to indicate the stiffness of the joint, which is determined experimentally in accordance with the standards EN 1075, EN 1380, EN 1381, EN 26891 and EN 28970.

In the PC SAPFIR the 3D-information model of the building with application of tools for creation of settlement schemes and their transfer for calculation in the PC LIRA-CAD is constructed.

The process of parametric design consists of determining the parameters, constructing relationships between them, determining the expected geometry, creating variations and testing the result [23]. The design with joint use of the PC SAPFIR and the PC LIRA-CAD allowed to consider requirements of ДБН and other regulatory documents.

Working with the SAPFIR PC revealed a number of limitations in functionality compared to Revit (Autodesk Revit PC). Revit integration with Robot PC (Autodesk Robot Structural Analysis) is a combination of software and computing systems designed for the design and calculation of buildings and structures in 3D space with the implementation of the BIM concept.

To create a 3D-information model, structural elements similar to the connection between the PC SAPFIR and the PC LIRASAPR are used. Since it was decided to test the LIRA-CAD PC for the possibility of modelling wooden structures using BIM technology, the use of the SAPFIR PC is most appropriate for building information and creating calculation models of complex elements with subsequent import of the model into the system. computer complex PC LIRA-CAD.

To simplify the model production, the following auxiliary steps were performed:

- creation of a 2D template in AutoCad with reference lines of the axes and the location of rigid walls on which the coverage is based and the import of the drawing into the SAPFIR PC in the form of a dxf-underlay, an analytical model is created automatically during the formation of the physical model;

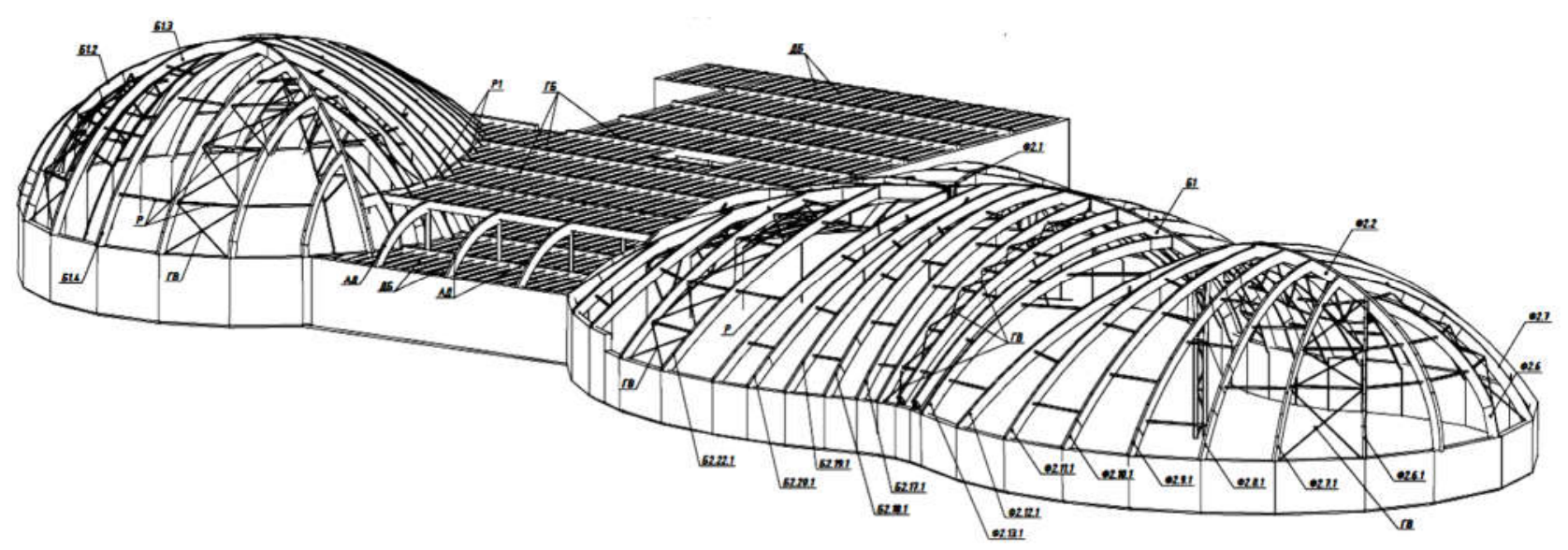

Fig. 8. Informational model from the PC Tekla Structures

Рис. 8. Інформаційна модель з ПК Tekla Structures 

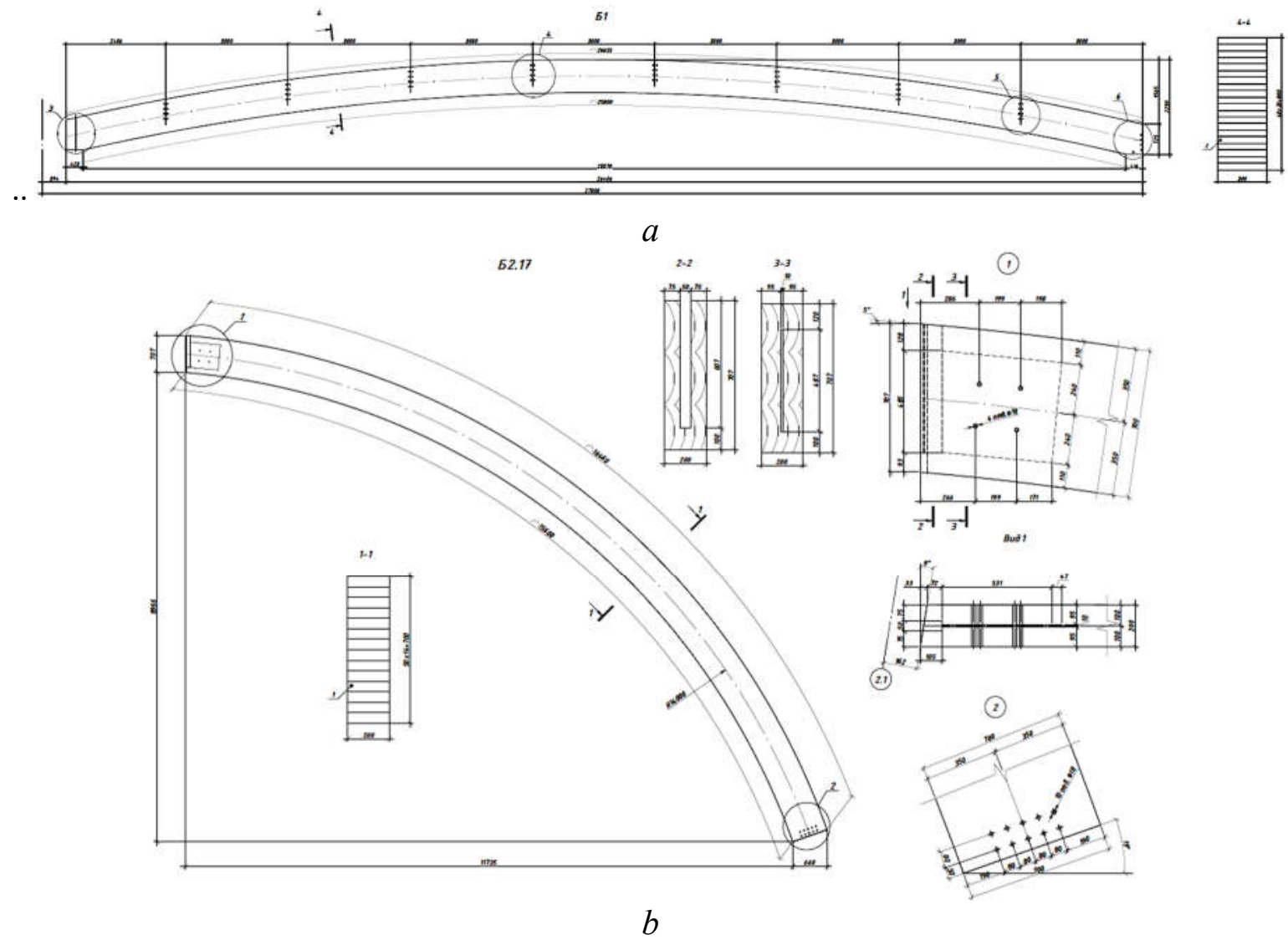

Fig. 9. Detailed drawings of curved wooden elements: $a$ - the main beam; $b$ - the dome rib

Рис. 9. Деталізовані креслення гнутих деревяних елементів: $a$ - головної балки; $b$ - ребра купола

- since the construction of elements in

the PC SAPFIR occurs only in the local coordinate system, for each element auxiliary lines were built for the correct orientation of the working plane in space. The created system can be customized.

Nodes designing. For the further development of effective nodal connections, 3D modeling was used with the transfer of the information model to the Tekla Structures PC, which is a specialized environment for the structural part of the project (Fig. 8). The information is exported to the Tekla PC using an IFC-file, but due to some differences in models and gaps that can accompany transitions between analysis and design diagrams, it is necessary to recognize the elements after importing the file. With the use of the Tekla information system, the construction of nodes and details, the creation of specifications and the printing of working drawings of the project were carried out. The main system nodes are fully designed and built.
The node 1 - support of the beam on the ring (Fig. 10, a). The design of the support ring and the configuration of the assembly depend on the size of the thrust plane, The following assembly details are calculated: the width of the end plate, the required length of the upper and lower bend, plate thickness, shear fillet welds and bolted joints when the plate is crushed by the roller in the holes.

The node 2 - support unit of the dome rib with the roller joint (Fig. 10,b). The following node details are calculated: roller, required width of the thrust plane during compression, pins on the side profiles, the thickness of the head plate when working in bending, thrust plate.

The node 3 - support of the beam on the column (Fig. 10,c) with the hinged joint. The following parts of the assembly were checked: timber during shear in the area of the assembly, stop height with local compression across the grain, bolts connecting the beam to the baseplate. 


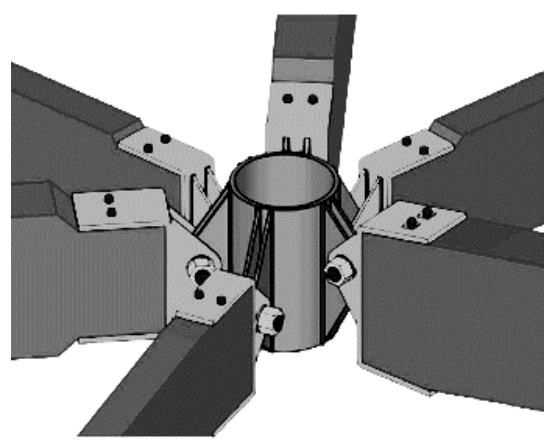

$a$

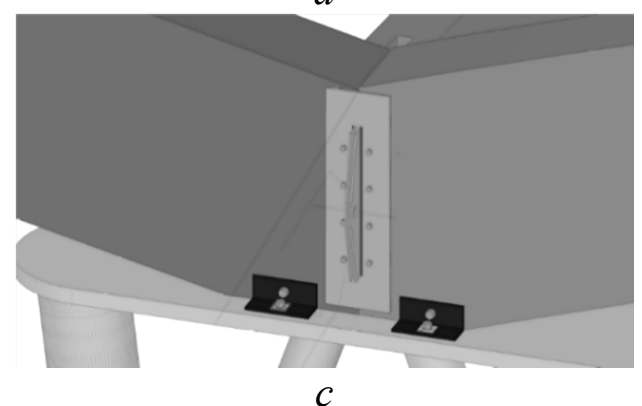

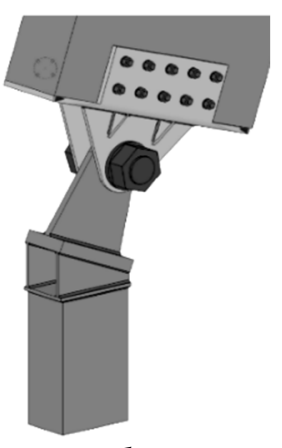

$b$

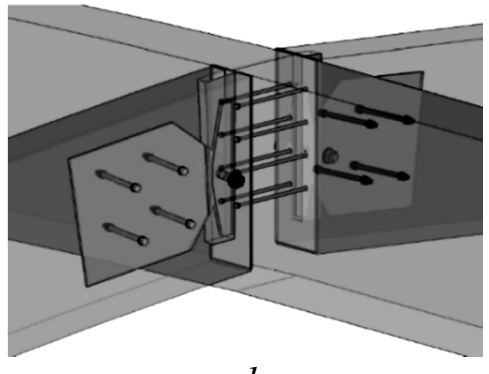

$d$

Fig. 10. 3D-model from the PC Tekla Structures: $a$ - support of the beam on the ring; $b$ - support unit of the dome rib with the roller joint; $c$ - support of the beam on the column; $d$-connection of the dome node with the main beam

Pис. 10. 3D-моделі вузлів 3 Tekla Structures: $a$ - обпирання балки на кільце; $b-$ опорний вузол ребра купола з валиковим шарніром; $c$ - обпирання балки на колону; $d$ - примикання ребра купола до головної балки

The node 4 - connection of the dome node with the main beam (Fig. 10, d). The unit consists of an embedded sheet in the cross-section of the beam and two plates with stiffening ribs between them.

Additionally, the fire resistance and subsidence of the foundation were analyzed

The analysis of the structural form and design models of the dome covering absorbed mainly the problems of structural strength and stability. However, there are a number of issues that cannot be addressed in this project. Such issues, which are not formalized within the narrow limits of the project, will be considered in a wide range:

- deformability of structures taking into account fluctuations in temperature and humidity;

- It is necessary to solve the problems of fire protection [12], development of fire scenarios to calculate fire resistance [24] and fire protection measures;

- special processing of connections and protection of details.
- design with the involvement of optimization procedures taking into account costs.

\section{CONCLUSIONS AND PROSPECTS FOR FURTHER RECEARCH}

1. The presented modeling of a complex dome structure using timber arches summarizes the approaches to the creation of unique forms of timber structures. Information modeling is virtually the only way to design complex timber structures. This makes it possible, even at the stages of designing, to resolve the issue of the accuracy of the calculation, erection and correct operation of such buildings.

2. An experimental project was completed using 3D-modeling, which confirmed the possibility of creating and editing the complex building model. The integrated use of information models has made it possible to reduce design efforts, simplify work processes and significantly increase the complexity of both architectural design and the analytical model, taking into account the nonlinear effects of wood. 
3. Further studies on the use of modeling in the design of wooden structures should be carried out with a detailed account of all the effects and regulations of the Eurocode related to operating conditions, technological requirements and fire resistance requirements.

4. The results of the project indicate the ability to actively integrate information modeling of complex structures into the BIM design environment. [28].

\section{REFERENSES}

1. Bilyk A.S., Beliaiev M.A., "BIM-modeliuvannia:ohliad mozhlyvostei ta perspektyvy $\mathrm{v}$ Ukraini“. Promyslove budivnytstvo ta inzhenerni sporudy, 2015. №2, pp.93-15.

2. Barabash M.S., Kompiuternoe modelyrovanye protsessov zhyznennoho tsykla obъektov stroytelstva: Monohrafyia, K., Stal, 2014.

3. Adamenko V. M., "Dosvid zastosuvannia BIM-tekhnolohii pry proektuvanni i rozrakhunkakh stalevykh ta zalizobetonnykh konstruktsii". Materialy dopovidei Pershoi vseukrainskoi naukovo-praktychnoi konferentsii: BIM- tekhnolohii v budivnytstvi: dosvid ta innovatsii, pp. 13-16, 2021.

4. R. Lancashire, L. Taylor. Innovative timber construction. New ways to achieve energy efficiency. TRADA Technology Ltd, 2012. 56 p.

5. Bobylev S.N., Ekolohyzatsyia ekonomycheskoho razvytyia, M., Ekonomyka, 2011.

6. Kaluhyn A.V., "Kleenye dereviannye konstruktsyy v sovremennom stroytelstve". Promyshlennoe y hrazhdanskoe stroytelstvo, № 7 (part 2), pp. 32- 37, 2011.

7. Lavrinenko L.I., Umanecz D.V. "Osoblyvosti proektuvannya ta analiz kons-truktyvnogo rishennya metalevogo kupolnogo pokryttya akvaparku". Mistobuduvannya ta terytorialne planuvannya. KNUBA, 2013. V. 50. Pp.328336.

8. Kienko Y.Y., Lavrinenko L.I., "Analiz stsenariiu prohresuiuchoho ruinuvannia sterzhnovoho kupola". Mistobuduvannia ta terytorialne planuvannia, KNUBA, vol. 64, pp. $108-114$, 2017.

9. Nawari N., "BIM Standardization and Wood Structures". International Conference on Computing in Civil Engineering, 2012. https://doi.org/10.1061/9780784412343.0037

10.Hossain F., "Advanced Building Design". Sustainable Design and Build, 2019 Kubba S., "Building Information Modeling
(BIM)". Handbook of Green Building Design and Construction (Second Edition), pp. 227256, 2017.

12. Merschbrock C., Digital Collaboration in the Wood-based Construction Industry. Deployment of Building Information Modeling: Doctoral Dissertation University of Agder Faculty of Social Science, 2014.

https://core.ac.uk/download/pdf/52083341.pdf,

13. Building Information Modeling (BIM) and Design for Manufacturing and Assembly (DfMA) for Mass Timber Construction, BIM Topics Lab, University of British Colunbia, 2018.

14. Koutamanis A., "Building information modeling for construction and demolition waste minimization", Advances in Construction and Demolition Waste Recycling, 592 p., 2020.

15. Sinopoli J., "Design, Construction, and Renovations". Smart Building Systems for Architects, Owners and Builders, pp. 139 - 158, 2010.

16. Porteous J., Ross P., Designer` Guide to Eurocode 5. Design of Timber Buildings EN 1995-1-1, M., MHSU, 2013.

17. Porteous J., Kermani A., Structural Timber Design To Eurocode 5, Blackwell Publishing, 2007.

18.Kachurovskyi A., Lyzohub E., "Konstruktyvnoe reshenye lehkoi strukturnoi obolochky bolsheproletnoho kupola", Arkhytekturnostroytelnyi portal, www ais.by, 2006

19. Kalkan E.,. Okur F.Y, Altunisik A.C., "Applications and usability of parametric modeling", Journal of Construction Engineering. Management and Innovation, №1(3), pp. 139146, 2018.

20. Barabash M.S., Kyivska K.I., "Kontseptsiia stvorennia informatsiinoi modeli budivelnoho obiektu", Problemy rozvytku miskoho seredovyshcha, vol. 1 (15), pp. 60-68, 2016.

21.Varenyk K.A., "Approksymatsyia dyahrammы deformyrovanyia drevesyn". Vestnyk Novhorodskoho Hosudarstvennoho unyversyteta. 2013. №75. т.1, pp.60-64

22. Mykhailenko O.A., "Kozhevnykova M.S. O vlyianyy anyzotropyy upruhykh svoistv drevesynы y fanerы na napriazhennodeformyrovannoe sostoianye кombynyrovannykh konstruktsyi". Tekhnycheskye nauky ot teoryy $k$ praktyke. №10(58). 2016, pp.118125

23.Smadych I.P., "Parametryzatsiia arkhitekturnykh rishen $\mathrm{v}$ BIM-seredovyshchi ektuvannia".Materialy dopovidei Pershoi 
vseukrainskoi naukovo-praktychnoi konferentsiBIM-tekhnolohii $v$ budivnytstvi: dosvid ta innovatsii». 2021, pp.61-64.

24. Lavrinenko L.I., Nekora V.S., "Doslidzhennia nahrivannia stalevoi balky $\mathrm{z}$ hofrovanoiu stinkoiu v umovakh pozhezhi”. Budivelni konstruktsii. Teoriia i praktyka, vol. 6, pp. 12 - 21, 2020. http://doi.org/10.32347/2522-4182.6.2020, pp.12 -21 .

25.Myers B.A. "Taxonomies of Visual Prigramming and Program Visualization". Journal of Visual Languages and Computing. 1990. №1, pp. 97- 123.

26.Horodetskyi A.S., Evzerov Y.D. Kompiuternye modely konstruktsii. K., Fakt, 2007. 394

27.Lavrinenko L.I., Budko T.H. "Zastosuvannia metodiv i modelei BIM-tekhnolohii pry proektuvanni kupolnoho pokryttia akvaparku z dereavianymy arkamy". Suchasni budivelni konstruktsii z metalu ta derevyny: Zbirnyk naukovykh prats, ODABA, 2021, vyp. 25, c.7284.

http://doi.org/10.31650/2707-3068-2021-2572-84

28.Bilyk S.I., Bilyk A.S. "Holovni napriamky suchasnoho rozvytku metalevykh konstruktsii budivel i sporud“. Suchasni budivelni konstruktsii z metalu ta derevyny. Zbirnyk naukovykh prats, ODABA, 2021, vyp. №25, s.5 -12 .

http://doi.org/10.31650/2707-3068-2021-25-5$\underline{12}$

\section{ЛІТЕРАТУРА}

1. Білик А.С., Белясв М.А. ВIMмоделювання: огляд можливостей та перспективи в Україні. Промислове будівництво та інженерні споруди, 2015. №2. С. 93-15.

2. Барабаш М. С. Компьютерное моделирование процессов жизненного цикла объектов строительства. Монография. К., Изд-во Сталь, 2014. $301 \mathrm{c}$.

3. Адаменко В. М. Досвід застосування ВIMтехнологій при проектуванні і розрахунках сталевих та залізобетонних конструкцій. Матеріали доповідей Периої всеукраїнської науково-практичної конференції «BIMтехнологї в будівництві: досвід та інноваuiï». 2021. C. 13-16.

4. R. Lancashire, L. Taylor. Innovative timber construction. New ways to achieve energy efficiency. TRADA Technology Ltd, 2012. 56 p.
5. Бобылев С.Н. Экологизация экономического развития. М., Экономика, 2011. 320 c.

6. Калугин А. В. Клееные деревянные конструкции в современном строительстве. Промышленное и гражданское строительство, 2011. № 7 (ч.2). С. 32- 37 .

7. Лавріненко Л.І., Уманець Д.В. Особливості проектування та аналіз конструктивного рішення металевого купольного покриття аквапарку. Містобудування та територіальне планування. КНУБА, 2013. Вип. 50. С. $328-336$.

8. Кієнко Є.Є., Лавріненко Л.І., Аналіз сценарію прогресуючого руйнування стержньового купола. Містобудування та територіальне планування. КНУБА, 2017. Вип. 64. С. $108-114$.

9. Nawari N.. BIM Standardization and Wood Structures. International Conference on Computing in Civil Engineering, 2012 https://doi.org/10.1061/9780784412343.0037/

10.Hossain F. . Advanced Building Design. Sustainable Design and Build, 2019. 592 p.

11. Kubba S.. Building Information Modeling (BIM). Handbook of Green Building Design and Construction (Second Edition), 2017. Pp. 227-256.

12. Merschbrock C.. Digital Collaboration in the Wood-based Construction Industry. Deployment of Building Information Modeling Doctoral Dissertation University of Agder Faculty of Social Science, 2014. https://core.ac.uk/download/pdf/52083341.pdf

13. Building Information Modeling (BIM) and Design for Manufacturing and Assembly (DfMA) for Mass Timber Construction. BIM Topics Lab, University of British Colunbia, 2018. $86 \mathrm{p}$.

14.Koutamanis A. Building information modeling for construction and demolition waste minimization. Advances in Construction and Demolition Waste Recycling, 2020. 592 p.

15. Sinopoli J. . Design, Construction, and Renovations. Smart Building Systems for Architects, Owners and Builders. 2010. Pp. $139-158$.

16.Порто Дж., Росс П.. Руководство по проектированию к Еврокоду 5: Проектирование деревянных конструкций EN 1995-1-1. М., МГСУ, 2013. $308 \mathrm{c}$.

17.Porteous J., Kermani A.. Structural Timber Design To Eurocode 5. Blackwell Publishing, 2007. $542 p$.

18.Качуровский А., Лизогуб Е. Конструктив- 
ное решение легкой структурной оболочки строительный портал, www ais.by. 2006

19.Kalkan E., Okur F.Y., Altunisik A.C.. Applications and usability of parametric modeling. Journal of Construction Engineering. Management and Innovation. 2018. №1(3). Pp. 139146

20.Барабаш М.С., Київська К.І. Концепція створення інформаційної моделі будівельного об'єкту. Проблеми розвитку міського середовища. 2016. Bun. 1 (15). C. $60-68$.

21.Вареник К.А. Аппроксимация диаграммы деформирования древесины. Вестник Новгородского Государственного университеma. 2013. №75. T.1. C. 60-64

22.Михайленко О.А., Кожевникова М.С. О влиянии анизотропии упругих свойств древесины и фанеры на напряженнодеформированное состояние комбинированных конструкций. Технические науки - от теории к практике. №10(58). 2016 г. С. $118-$ 125

23.Смадич І.П. Параметризація архітектурних рішень в ВIM-середовищі проектування. Матеріали доповідей Першої всеукраӥнської науково-практичної конференції «ВIMтехнології в будівництві: досвід та інноваuiï». 2021. C. 61-64.

24.Лавріненко Л.І., Некора В.С. Дослідження нагрівання сталевої балки з гофрованою стінкою в умовах пожежі. Будівельні конструкиіі. Теорія і практика. Bun.6 (2020) C. 12 21. 4182.6.2020.12-21.

25..Myers B.A. Taxonomies of Visual Prigramming and Program Visualization. Journal of Visual Languages and Computing. 1990. №1. C. 97-123.

26.Городецкий А.С., Евзеров И.Д. Компьютерные модели конструкций. К., Факт, 2007. $394 c$.

27.Лавріненко Л.І., Будко Т.Г. Застосування методів i моделей ВIM-технологій при проектуванні купольного покриття аквапарку з дерев'яними арками. Сучасні будівельні конструкиії з металу та деревини: Збірник наукових пращь, ОДАБА, 2021, вип. №25, c. $72-84$.

http://doi.org/10.31650/2707-3068-2021-25$\underline{72-84}$

28.Білик С.І., Білик А.С. Головні напрямки сучасного розвитку металевих конструкцій будівель і споруд. Сучасні будівельні конструкиї з металу та деревини: Збірник наукових пращь, ОДАБА, 2021, вип. №25, с.5 - большепролетного купола. Архитектурно12. http://doi.org/10.31650/2707-3068-2021$\underline{25-5-12}$

\section{Конструктивний аналіз та 3D-моделювання просторової дерев'яної конструкції}

\section{Тетяна Будко, Людмила Лавріненко}

Анотація Проведено аналіз конструктивної форми мультиоб'ємної купольної будівлі з використанням несучих дерев'яних конструкцій. Складність об'ємів та їх сполучних ліній, а також вимога провести нелінійний аналіз дерев'яних елементів великого прольоту за рекомендаціями Єврокоду 5, роблять інформаційну модель необхідною. Відмічено, що інформаційне моделювання дерев'яних конструкцій у світі є найбільш підготовленим до використання ВІМ-технологій, що пов'язано з високою фабричною готовністю та складними цифровими технологіями виробництва сучасних елементів дерев'яних конструкцій масового виготовлення. При розробці проекту для українських умов та у відповідності з чинними нормами проектування була сформульована інформаційна модель в САПФІР ПК з подальшою можливістю імпорту моделі в ПК ЛІРА-САПР. Для побудови моделі були використані необхідні допоміжні кроки. Навантаження на криволінійну поверхню розраховані в ПК Еspri. Для подальшої розробки вузлів було використано 3Dмоделювання 3 передачею інформаційної моделі на ПК Tekla Structures як спеціалізованого середовища для конструктивного розділу проекту.

Представлений аналіз складної купольної конструкції 3 використанням дерев'яних арок узагальнюе підходи до розробки унікальних форм конструкцій 3 використанням дерева. Використання інформаційних моделей дозволило реалізувати складне архітектурнопланувальне рішення та суттєво збільшити складність конструктивної моделі з урахуванням нелінійних ефектів деревини.

Результати проекту вказують на можливість активної інтеграції інформаційних моделей дерев'яних конструкцій у проектування програмного середовища BIM.

Ключові слова. ВІМ-технологія; гнутоклеєні дерев'яні конструкції; купол; аквапарк; Єврокод 5 